\title{
Service Dominant Logic, Co-production and Co-creation: Model Development and Specifications
}

\author{
Onyechi Leonard Uzoka \\ Department of Marketing, Faculty of Management Sciences Chukwuemeka \\ Odumegwu Ojukwu UniversityPMB 6059, Igbariam , Anambra State, Nigeria
}

\section{The research is self financed}

\section{Abstract}

This paper set forth to examine the Service Dominant Logic paradigm, which is developed as an alternative paradigm to the Goods Dominant Logic, explore the developments that have occurred since its appearance in the Vargo and Lusch (2004) publication and attempt to identify the variables in this SD logic, as well as, its propositions; service co-production and value co-creation with the aim of verifying whether, or otherwise, the associated marketing variables could be put into operational model-building. The study found that there were identified marketing variables and using the assumption of linear relationship established multiple regression equations, it was found that it is feasible for such models, even more complex ones, conceptually to be developed in the foreseeable future. The paper does not claim to be exhaustive or definitive, but asserts that its usefulness lies in its demonstration that the time has come to start extensive research in making operational the SD Logic, lending it to closer scrutiny and academic/practical marketing investigations and use.

Keywords: Marketing, service dominant logic, service co-production, value co-creation, model-building DOI: $10.7176 / \mathrm{JMCR} / 64-03$

Publication date: January $31^{\text {st }} 2020$

\subsection{Introduction}

Marketing is an evolving discipline, often expanding and contracting, converging at times with or at other times aggressively diverging from other disciplines. This is a testament of the very rich research and professional efforts of both practitioners and academics in its various subject areas and schools of thought. The common denominator of this dynamics, remains the quest to make it more unique focused, and in that way develop and acquire sound theoretical and practical foundations.

\subsection{Background and purpose}

According to Vargo, and Akaka (2009) "Generally, there are two service(s) orientations that could inform service science. One is grounded in the traditional view of economic exchange and value creation as primarily involving goods (tangible products), with services conceptualized relative to goods, either as add-ons to (e.g., after-sale service) or a special type (i.e., intangible products)".

"This orientation has been called "goods-dominant (G-D) logic" (Vargo and Lusch 2004; 2008). Alternatively, $S-D$ logic considers service in its own right (i.e., without reference to goods) as central to economic exchange and value creation, though it sees goods as playing a central role in service provision." According to Ballantyne, Williams and Aitken (2011) "this endeavour stands in opposition to 200 years of mainstream economic logic in which marketing's most resilient assumptions are anchored".

As premise for their quest for a new perspective, Vargo and Lusch (2004) stated that "Marketing inherited a model of exchange from economics, which had a dominant logic based on the exchange of 'goods,' which usually are manufactured output. The dominant logic focused on tangible resources, embedded value, and transactions." They further stated their "believe that the new perspectives are converging to form a new dominant logic for marketing, one in which service provision rather than goods is fundamental to economic exchange" (Vargo and Lusch, 2004). Their belief in the SD Logic has largely become hotly debated and in significant quarters held as the new dominant logic in marketing.

In effort to advocate making the paradigm change from Goods Dominant to SD Logic, various authors have made effort to demonstrate the potentials of the use of this Logic. Fuentes and Smyth (2016) for example, in trying to advocate deployment of the SD logic stated among other things that "few projects configure and design value propositions to deliver a service experience and value beyond the minimum requirements." They stated further that there are potential benefits that precipitate the need to make operational SD Logic as follows: "It offers a fresh perspective to see projects as a service focusing on outcomes... provides an alternative standpoint to analyse the benefits delivery and effectiveness for the long-term: value-in-use and context." However, they state "Service-Dominant Logic needs to be made operational as it might not work in isolation." (Fuentes and Smyth, 2016)

That paper did not end up making 'operational' the concept, but did show the link between Service Dominant Logic and Service Design in project management. Karpen, Bove, and Lukas (2012) have also argued 
that using this SD logic that "overall, firms prioritize valuable interaction experiences and outcomes of reciprocal resource integration efforts, rather than focusing on products per se, thereby forming the basis for successful future strategies". Going further, Karpen et al (2012) have opined that "service-dominant (S-D) logic, interpreted as strategic business logic, portrays creating value in conjunction with-rather than for-customers as a source of competitive advantage for organizations." Meanwhile "the managerial merits of co-creating value have been discussed in the literature, less is known about the organizational capabilities necessary to execute S-D logic in practice." (Karpen et al, 2012)

\subsection{Aims and justification}

This paper aims to conduct a literature review in the area of SD logic, the creation and co-creation of value arguments and explore possibility of making the resultant relationships operational. In this direction, it becomes necessary to, explore the SD logic's original propositions, significance of propositions as stated by its proponents, the arguments against its proposed use in marketing, look at the arguments against its use in marketing, investigate the potentials of making the propositions operational and possibly profer a model(s) with its variables in a precise model for marketing. When this is done it is envisaged that it will open up designing of different models for different aspect of the SD logic and encourage empirical investigations and rendering operational this dominant logic for practical application at the micromarketing level.

\subsection{Literature review}

2.1 Service dominant logic and its original proponents, propositions and discussion for and against.

Vargo and Akaka (2009) observed that "S-D logic proposes an alternative perspective for the study of economic exchange, which actually is more consistent with Smith's more foundational notions of real value (applied, specialized knowledge) and value-in-use than the GD logic that grew out of his restricted work on national wealth creation. This service-centred view suggests that market exchange is the process of parties using their specialized knowledge for each other's benefit - that is, for mutual service provision." According to Kanagal (2014) the process of delivery of superior customer value is enhanced if firms have the right targets and assess their business marketing performance in a timely, consistent and effective way. According to Vargo and Lusch (2004) the fundamental premises of the service dominant logic is as follow:

"FP 1: the application of specialized skills and knowledge is the fundamental unit of exchange

FP 2: indirect exchange masks the fundamental unit of exchange

FP 3: goods are distribution mechanisms for service provision

FP 4: knowledge is the fundamental source of competitive advantage

FP 5: all economies are services economies

FP6: the customer is always a co-producer

FP 7: the enterprise can only make value propositions

FP 8: a service-centred view is customer oriented and relational"

The SD logic and these fundamental premises were subsequently subjected to series of debates and critiques by marketing academics and practitioners. The debates were in most occasions started and stimulated by the chief proponents Lusch and Vargo and what developed was or could have been described as an avalanche of articles, books and seminars and conferences that were as diverse as one would expect from academics. Some of the discussions were outright opposition to the SD logic; others were in support and were already clamouring for its immediate application. While others were busy trying to make more sense out of the confusion that was threatening to set in. We have set some of these articles in table 2.1 below. The literature reviewed is in no way exhaustive, but they do point to the liveliness and level of interest in the SD logic, post its entry into marketing domain. 
Table 2.1:Review of some Literature and post -Vargo and Lusch (2004) Service-dominant logic foundational premise as at 2008

\begin{tabular}{|c|c|c|c|}
\hline $\mathrm{S} / \mathrm{n}$ & $\begin{array}{l}\text { Authors /year of } \\
\text { publication }\end{array}$ & Title of publications & Contributions \\
\hline 1 & $\begin{array}{l}\text { Lusch, R. F. and } \\
\text { S. L. Vargo } \\
(2006) \text { editors }\end{array}$ & $\begin{array}{l}\text { "The service-dominant } \\
\text { logic of marketing : dialog, } \\
\text { debate, and directions" }\end{array}$ & $\begin{array}{l}\text { Compilation of } 30 \text { articles on various areas of the SD } \\
\text { logic: } \\
\text { * "primary purpose in initiating this book of essays is } \\
\text { to extend and expand the creative } \\
\text { * "exploration and development of this "new dominant } \\
\text { logic" for marketing, and thus to take one additional } \\
\text { step in a continuing process of "getting it right." } \\
\text { "examine the foundational aspects of S-D logic." } \\
\text { some new } \\
\text { *"research directions opened up by adopting the } \\
\text { evolving logic of firm-consumer value creation." }\end{array}$ \\
\hline 3 & $\begin{array}{l}\text { Grönroos, } \\
(2006)\end{array}$ & $\begin{array}{l}\text { "Adopting a service logic } \\
\text { for marketing." }\end{array}$ & $\begin{array}{l}\text { "This article demonstrates that a service marketing } \\
\text { context and a service logic rather than a goods } \\
\text { marketing context and a goods logic are the norm and } \\
\text { not a special case." }\end{array}$ \\
\hline 4 & $\begin{array}{l}\text { Abela, A. V., and } \\
\text { P. E. Murphy } \\
(2008) \text {. }\end{array}$ & $\begin{array}{l}\text { "Marketing with integrity: } \\
\text { ethics and the service } \\
\text { dominant logic for } \\
\text { marketing." }\end{array}$ & $\begin{array}{l}\text { "Firms should begin to build a reputation as a } \\
\text { trustworthy and fair partner that treats co-creators with } \\
\text { care and respect." }\end{array}$ \\
\hline 5 & $\begin{array}{l}\text { Arnould, E. J. } \\
(2006)\end{array}$ & $\begin{array}{l}\text { "Service-dominant logic } \\
\text { and consumer culture } \\
\text { theory: Natural allies in an } \\
\text { emerging paradigm" }\end{array}$ & $\begin{array}{l}\text { "Some of the propositions outlined in Vargo and Lusch } \\
\text { (2004) are ideas that researchers associated with the } \\
\text { Consumer Culture Theory tradition have pioneered. } \\
\text { Need to acknowledge this and work together" }\end{array}$ \\
\hline 6 & $\begin{array}{l}\text { Lusch, R. F., \& } \\
\text { Vargo, } \\
\text { (2006). }\end{array}$ & $\begin{array}{l}\text { "The service-dominant } \\
\text { logic of marketing: } \\
\text { Reactions, reflections, and } \\
\text { refinements." }\end{array}$ & $\begin{array}{l}\text { "Five recurring, contentious issues among } \\
\text { collaborating scholars, nature and scope of S-D logic, } \\
\text { are identified and are clarified and refined, as is } \\
\text { appropriate to this co-creation of a service-centric } \\
\text { philosophy by the worldwide marketing community." }\end{array}$ \\
\hline 7 & $\begin{array}{l}\text { Lusch, R. F., } \\
\text { Vargo, S. L., and } \\
\text { M. O'Brien, } \\
(2007) .\end{array}$ & $\begin{array}{l}\text { "Competing through } \\
\text { service: Insights from } \\
\text { service-dominant logic" }\end{array}$ & $\begin{array}{l}\text { "Relying upon the nine foundational premises of S-D } \\
\text { logic... nine derivative propositions are developed that } \\
\text { inform marketers on how to compete through service" }\end{array}$ \\
\hline 8 & $\begin{array}{l}\text { Michel, } \quad \text { S., } \\
\text { Stephen, W., and } \\
\text { A. S. Gallen } \\
(2008) .\end{array}$ & $\begin{array}{l}\text { An expanded and } \\
\text { strategic view of } \\
\text { discontinuous } \\
\text { innovations: deploying } \\
\text { a service-dominant } \\
\text { logic }\end{array}$ & $\begin{array}{l}\text { "Innovations can be better understood by } \\
\text { deploying an S-D logic perspective." }\end{array}$ \\
\hline
\end{tabular}

Sources: various authors as discussed in the table

These original propositions were reviewed and further expanded as a result of the heated debates on the subject of SD logic by the duo of Vargo and Lusch in 2008. The table 2.2 below shows the 10 prepositions as put forward by the authors. 
Table 2.2: Service-dominant logic foundational premise modifications and additions

\begin{tabular}{llrll}
\hline FPs & $\begin{array}{l}\text { Original foundational } \\
\text { premise }\end{array}$ & $\begin{array}{l}\text { Modified/new foundational } \\
\text { premise }\end{array}$ & Comment/explanation \\
\hline FP1 & $\begin{array}{l}\text { The application of } \\
\text { specialized skill(s) and }\end{array}$ & $\begin{array}{l}\text { Service is the fundamental } \\
\text { basis of exchange }\end{array}$ & $\begin{array}{l}\text { The application of operant resources } \\
\text { (knowledge and skills), "service," as defined in }\end{array}$ \\
& $\begin{array}{l}\text { knowledge is the } \\
\text { fundamental unit of }\end{array}$ & $\begin{array}{l}\text { S-D logic, is the basis for all exchange. Service } \\
\text { is exchanged for service }\end{array}$
\end{tabular}

FP2 Indirect exchange masks Indirect exchange masks the fundamental unit of the exchange

FP3 Goods are a distribution mechanism for service provision

FP4 Knowledge is the fundamental source of competitive advantage

FP5 All economies are services economies

are

fundamental exchange

Goods are a distribution mechanism for service Provision

Operant resources are the fundamental source of competitive advantage

All economies are service economies

FP6 The customer is always a co-producer

FP7 The enterprise can only make value propositions

A service-centred view is customer oriented and relational

FP9 Organizations exist to integrate and transform micro specialized competences into complex services that are demanded in the marketplace
The customer is always a co-creator of value

The enterprise cannot deliver value, but only offer value propositions

A service-centred view is inherently customer oriented and relational

All social and economic actors are resource integrators
Because service is provided through complex combinations of goods, money, and institutions, the service basis of exchange is not always apparent

Goods (both durable and non-durable) derive their value through use - the service they provide

The comparative ability to cause desired change drives competition

Service (singular) is only now becoming more apparent with increased specialization and Outsourcing

Implies value creation is interactional

Enterprises can offer their applied resources for value creation and collaboratively (interactively) create value following acceptance of value propositions, but cannot create and/or deliver value independently

Because service is defined in terms of customerdetermined benefit and co-created it is inherently customer oriented and relational Implies the context of value creation is networks of networks

Value is always uniquely and phenomenologically determined by the beneficiary
Value is idiosyncratic, experiential, contextual, and meaning laden

Source: Vargo S. L. and Lusch, R. F. (2008) service-dominant logic: continuing the evolution. Journal of the Academy of Marketing Science, 36: 1-10.

Thus two additional premises were effectively put forward by the original authors in reply to the critiques of the inadequacies observed by other authors between 2004 and 2008.

Vargo, and Akaka (2009) Commenting on foundational propositions FP1 and FP5 "S-D logic's basic tenet is that service (singular, indicating a process vs. the plural "services," indicating intangible units of output) - the application of competences for the benefit of another - is the basis of all exchange (FP1). In other words, service is always exchanged for service; thus all economies are service economies (FP5)". They go further to observed about FP2 and FP3 that "the process of value creation within and between service systems becomes increasingly complex and less apparent as intermediary systems develop. In S-D logic, these market related intermediaries (e.g., goods, money and organizations) maintain important roles in facilitating the process of exchange (FP3). However, they are not the primary purpose or fundamental source of exchange and value creation."

Brodie, Glynn, and Little (2006) in furthering the use of SDL as proposed by Vargo and Lusch (2004) have "argued both conceptually and by using empirical evidence that 'the service brand' in its role as a relational asset is a fundamental and central concept within the S-D logic. Therefore, if the S-D logic is to be relevant to marketing practice then more attention needs to be given to its role." Furthermore, Brodie, Glynn, and Little 
(2006) argued that;

"While a strong case can be made for introducing a fundamental premise about the service brand, we conclude that it is more appropriate to consider it as a corollary to Vargo and Lusch's (2006) emerging ninth proposition about resource integration and co-creation of value. However, before doing this, further attention needs to be given to integrating the concepts of brand equity, customer equity and network equity into a theory of marketplace equity."

Karpen, Bove, and Lukas (2012) opined that SD logic "overall, firms prioritize valuable interaction experiences and outcomes of reciprocal resource integration efforts, rather than focusing on products per se, thereby forming the basis for successful future strategies".

Furthermore, to get beyond further arguments for revisiting the 10 propositions, Gronroos (2011) arguments have shown that some of the propositions where either not supportive or were contradictory to each other. These had caused Gronroos to compare and either eliminate or merge some of the propositions of Vargo and Lusch (2008) and these are summarised in the following table 2.3:

Table 2.3: Foundational premises related to value creation according to Vargo and Lusch, 2008

\begin{tabular}{|c|c|c|}
\hline \multicolumn{2}{|c|}{ Foundational premises related to value creation } & \multirow[b]{2}{*}{$\begin{array}{l}\text { Implication } \\
\text { The ultimate basis of activities performed by } \\
\text { parties engaged in business is to provide } \\
\text { service }\end{array}$} \\
\hline No. 1 & $\begin{array}{l}\text { Service is the fundamental basis of business } \\
\text { ("Service is exchanged for service") }\end{array}$ & \\
\hline No. 3 & $\begin{array}{l}\text { Goods are a distribution mechanism for service } \\
\text { provision }\end{array}$ & $\begin{array}{l}\text { Goods have no value in themselves, but only } \\
\text { as transmitters of service for the user }\end{array}$ \\
\hline No. 6 & The customer is always a co-creator of value & $\begin{array}{l}\text { The customer as user is always involved in } \\
\text { the value-creation process }\end{array}$ \\
\hline No. $7 \mathrm{a}$ & The firm cannot deliver value & $\begin{array}{l}\text { Value is not embedded in resources delivered by } \\
\text { the firm. Hence, the firm cannot produce value. }\end{array}$ \\
\hline No. $7 \mathrm{~b}$ & The firm can only offer value propositions & $\begin{array}{l}\text { The firm cannot engage itself with the } \\
\text { customer's value creation and influence it }\end{array}$ \\
\hline No. 9 & $\begin{array}{l}\text { All social and economic actors are resource } \\
\text { integrators }\end{array}$ & $\begin{array}{l}\text { Consumption/usage is about integrating } \\
\text { resources acquired from different sources } \\
\text { into a usage process }\end{array}$ \\
\hline No. 10 & $\begin{array}{l}\text { Value is always uniquely } \\
\text { phenomenologically determined by } \\
\text { beneficiary } \\
\text { (e.g. in a business context the customer ) }\end{array}$ & $\begin{array}{l}\text { In a business context the customer and only the } \\
\text { customer determines what value is created (or } \\
\text { emerges) for him-/herself in } \\
\text { the specific context of usage }\end{array}$ \\
\hline
\end{tabular}

Source: Gronroos, C. (2011) Value co-creation in service logic: A critical analysis. Marketing Theory 11(3): 281

We also are in agreement with the views of Gronroos (2011) that the adjustments should be made to eliminate the contradictions and this therefore sets the basis for the next sections of this paper.

\subsection{Conceptual framework to put SD Logic to empirical verification; way forward}

According to Lamberti and Paladino (2013) "Service Dominant Logic (SDL) has been the subject of great conceptual debate over the past years. We are now clearly at a crossroad where application is required to cement its practical relevance to the organization and its performance." In their 2013 work cited above their aim was to "develop a comprehensive framework and lay the foundation for the initiation of empirical work on SDL to further enrich the work initiated by Vargo and Lusch (2004)" Lamberti and Paladino (2013) stated that their work "tackled with reinforcing the linkage between the SDL theory and current managerial and marketing wisdom and to set the basis for a development of empirical research on SDL. Indeed, we hope that this review will motivate an empirical stream of inquiry to further our knowledge and understanding of the applicability of this area of research." We perceive that the authors of that research effort believed that they have laid the foundations for the next step in putting the SDL more closely to academic and practical use. The next step, we have conceived, is to make operational this concept by using the mathematical modelling approach.

According to Gronroos (2011) it is observed that "the unique contribution of a service perspective on business (service logic) is not that customers always are co-creator of value, but that under certain circumstances the service provider gets opportunities to co-create value together with its customers". He therefore reformulated six statements excluding three and including seven of Lusch and Vargo (2006) fundamental premises as follows:

1. "Reciprocal value creation is the fundamental basis of business, with service as a mediating factor. That is goods are distribution mechanism for service provision all resources and processes are distribution mechanisms for service provision, however without including value in them.

2. Fundamentally, the customer is always a value creator. Accordingly the firm cannot deliver value... However taking into consideration when considering the underpinning logic of the interaction concept, the situation becomes more complex. Consequently, the firms role in value creation is two folds: 
3. Fundamentally, the firm is a facilitator of value for the customer...That is, the firm can only offer value propositions

4. Provided that the firm can engage with its customers' value-creating processes during direct interactions, it also has opportunities to co-create value jointly with them.

5. Value is accumulated throughout the customer's value- creating process. Value is always uniquely and phenomenologically determined by beneficiary. That is value is determined by the customer.

6. Value is always uniquely and both experientially and contextually perceived and determined by the customer." (Gronroos, 2011)

The implication of these six statements would be that firms prior to offering value propositions and in mapping their courses of action, must first know what, why, where, how and when their customers buy and consume the product and then anticpate and plan on viable strategies to insert the firm into the value creation process. The firm would then be in a unique position for not only offering but, also engage in value co-creation. The presence of the firm in the value creation situation is as important as offering value propositions. The offer of value proposition should, as of necessity, follow contemporary processes and relevant issues like branding, quality assurance, innovation, customer engagement directly and indirectly through communication and direct marketing and so on. The strategies to be adopted must be holistic encompassing the pre value proposition, service production and post service delivery through the value creation process and the post value creation process. This would be viewed as a dynamic and cyclical process for the experiential element of the process for both the firm and the customer to come into play. Layton (2008), though talking about the meso-macro levels in marketing discussions, supports this dynamic, cyclical rather than static view thus: "A service-dominant view of economic exchange recognises the fundamental role of specialised skills and knowledge in the co-creation of value. This is an inherently dynamic view of the processes involved, as knowledge is not static but changes through learning and experience."

\subsection{Methodology}

\subsection{Service dominant logic: a firm's perspectives, analysis and model building}

The implications of the above discuss in previous sections of this paper are first, that all production and marketing efforts of the firm must be viewed as 'product' delivering service(s) (facilitator of values) to the customer. Therefore, our first premise is that given that the consumer is a co-producer of the service offer the firm is assured of its possible use in the value creation process. However, contrary to Lusch and Vargo (2004)' 'FP6' premise, that "the Customer Is Always a Co-producer", and contrary to Gonroos (2011)' equation of 'coproduction' with 'co-creation', we hold that a consumer is not always a co-producer, but a potential co-producer. This implies that if the consumer is invited to coproduce by the firm and accepts this invitation then and only then does the consumer co produce service offering. In the same vain in respect of co-creation, the opposite is the case of value creation in which the consumer's permission is required for co creation of value to take place and this leads us to the $2^{\text {nd }}$ premise.

The second premise is; on receipt of the services, if the customer shuts the door and does not invite the firm in and goes on to create value with the services provided, the company cannot co-create value. This is so even if the firm and the consumer co-produced (prior to co-creation) the value offer, i.e. the service. As it is in the interest of the firm (that is, co-creation increases ability to influence the value creation experience), the firm needs to seek out avenues for the customer to open the door for the firm to come in and co-create value. So, perpetually the firm should be alert and make conscious effort (research based development of customer centred strategies) to know when to either ask for or when the opportunity for this open door is offered so that it can be part of the co-creation process. This now leads us to two distinct situations for interaction between the firm and the consumer;

i. Possibility of co-production of services by the firm and its customer/consumer

ii. Possibility of co-creation of value by the firm and its customer/consumer

\subsection{Possibility of co-production of services by the firm and its customer/consumer} We propose the first relationship could proceed as follows:

$$
\mathrm{Sr}=f(\mathrm{Me}, \mathrm{O}, \mathrm{T})
$$

Where the firm does not involve the customers and

' $\mathrm{Sr}$ ' is service offer production

As a function of:

'Me' which is the marketing efforts of the firm i.e. the marketing mix application

' $\mathrm{O}$ ' being opportunities to market the service offer

And

' $\mathrm{T}$ ' being the threats in the environment including competitive actions and competing service offers can be expanded if we assume, for simplicity sake, a linear relationship as follows 
Where

$$
\mathrm{Me}_{\mathrm{t}-\mathrm{n}}=\beta_{\mathrm{o}}+\beta_{1} \mathrm{Pr}_{\mathrm{t}-\mathrm{n}}+\beta_{2} \mathrm{Pd}_{\mathrm{t}-\mathrm{n}}+\beta_{3} \mathrm{Pl}_{\mathrm{t}-\mathrm{n}}+\beta_{4} \mathrm{Pm}_{\mathrm{t}-\mathrm{n}}+\varepsilon
$$

Me is the marketing effort of the firm and

$\mathrm{Pr}_{\mathrm{t}-\mathrm{n}}$ is the price set at time $\mathrm{t}-\mathrm{n}$

$\mathrm{Pd}_{\mathrm{t}-\mathrm{n}}$ is the service (product) offered at time $\mathrm{t}-\mathrm{n}$

$\mathrm{Pl}_{\mathrm{t}-\mathrm{n}}$ is the spatial, or medium (place) at and/or through which service is offered and provided at

time $\mathrm{t}-\mathrm{n}$

$\mathrm{Pm}_{\mathrm{t}-\mathrm{n}}$ is the promotion given as part of the service offer

$\varepsilon$ is the error term

And service offer, $\mathrm{Sr}$ at time $\mathrm{t}$ would be represented by

$$
\mathrm{Sr}_{\mathrm{t}}=\beta \mathrm{o}+\beta_{1} \mathrm{Me}_{\mathrm{t}-\mathrm{n}}+\beta_{2} \mathrm{O}_{\mathrm{t}-\mathrm{n}}+\beta_{3} \mathrm{~T}_{\mathrm{t}-\mathrm{n}}+\varepsilon
$$

3.3 Possibility of co-creation of value by the firm and its customer/consumer

This situation could theoretically be conceived as a linear relationship (again for the sake of simplicity) as follows;

$$
\mathrm{Vc}_{\mathrm{t}}=f \text { (services, value in use) }
$$

That is; Customer creates value alone

$\mathrm{Vc}_{\mathrm{t}}=f$ (services, customers input),

Customer and firm create value together

$\mathrm{Vc}_{\mathrm{t}}=f$ (services, firm's input, customers input)

Or more specifically

Door is closed:

$$
\mathrm{Vc}_{\mathrm{t}}=f\left(\mathrm{Sr}_{\mathrm{t}-\mathrm{n},}, \mathrm{Ce}_{\mathrm{t}}, \varepsilon\right) \text {-------- customer creation of value }
$$

Where: $V c_{t}$ is the Value created at a time $\mathrm{t}, f$ is a function of

Sr Services offered for creation of value by the firm at a time t-n

$\mathrm{Ce}_{\mathrm{t}}$ is the customer input and experiences garnered alone

$\varepsilon$ is the error term

Door is opened to firm to come in and possibly co-create

$$
\mathrm{Vc}_{\mathrm{t}}=f\left(\mathrm{Sr}_{\mathrm{t}-\mathrm{n}, \mathrm{Ce}}, \mathrm{E}\right) \text {-------------------co-creation }
$$

$\varepsilon$ is the error term

This time customer input, includes the input of the customer plus the influence of the firm's involvement

$$
\mathrm{Ce}_{\mathrm{t}}=f\left(\mathrm{fe}_{\mathrm{t}}, \mathrm{Ci}_{\mathrm{t}}, \varepsilon\right) \text {-----------Customers input and experience }
$$

Where $\mathrm{fe}_{\mathrm{t}}$ is the firm's inputs during co-creation

$\mathrm{Ci}_{\mathrm{t}}$ is the customer's inputs and experience during interaction and co-creation

$\varepsilon$ is the error term

$\mathrm{Sr}_{\mathrm{t}-\mathrm{n}}$ Services offered for creation of value by the firm at a time $\mathrm{t}-\mathrm{n}$

\subsection{Discussion}

\subsection{Making the SD-logic operational in marketing practice}

To make these variables operational in terms of marketing decision making and evaluation we need to make these variables a part of the marketing strategic options. This is where the marketing mix concept enters the proposed model building efforts. According to Lonhe (2014) "marketing is a matching process, one that pairs the capabilities of a company and the wants of the customers. The creation and delivery of unique value to prospective customers and acquire a sustained competitive advantage is of prime importance in marketing. Marketing mix is a tool used for effective marketing for decades" These could logically include the following 4Ps or any others like the 4Vs (Lonhe, 2014) mix offered:

a) Product (service offer) including actual generic "goods and services" including the packaging offered services as facilitators or services purely offered as conveyer of values in their own right

b) Price at which the product is offered

c) Place is where purchase and/or consumption could take place

d) Promotion that took place before and after purchase and before value creation. If the promotion occurred during creation, this could also cause co-creation.

We are mindful of the criticism of the McCarthy (1964)'s 4Ps concept and hold that whatever the type of marketing mix concept employed, the model proposed can be adapted to suit such strategic mixes. This makes it imperative and very important for the firm to consciously seek to know and 'monitor' it's customers, their 
preferences, where, when and how they consume the firms products and research on ways and strategies of asking for permission to have the doors open to that place/space/time value is to be created and anticipate when that opportunity presents itself in order not to miss co-creation which enhances the possibility of the firms active participation in the future. This is supported by Gronroos (2011) who posited that "although the consumers are in charge of their value creation and fundamentally are the value creators, during direct interactions, provided that the firm makes use of the opportunities of such an interactive process, the firm also co-creates value with the customers."

$\mathrm{fe}_{\mathrm{t}}$ is the firm's inputs during co-creation and could logically include the following;

a) Store atmosphere if the value is created in the store i.e. Consumption goes on in the store( i.e. restaurant)

b) After sales services for vehicles, warrantee implementation etc

c) Training to use equipment like learning to operate a new phone or home appliance

d) Training to learn a software.

e) Tutorials built into programmes like "Microsoft Office Tutor or help"

f) In use consultations, communications over the phone, internet, etc on websites dedicated to assisting customers when using the firm's products.

g) In use product improvements and upgrades like "Windows Operating System" of Microsoft or "Avast antivirus programme" which interacts during usage of computer

h) Direct contact with customer while service is provided like in a hotel' meals, cleaning and other room services

i) Offer of free trail i.e. Sale of palm wine by local retailers, Auction of art works in a gallery, car test driving by customer and so on

j) Game shows that ask customers to use the product of the firm to interact with the firm. For example the "MTN who wants to be a millionaire", "Maltina Dance Hall" and sponsorship of the European Football Cup UEFA by Nigerian Breweries Plc. On television and setting up of viewing centres where their brand of beer, 'Heineken' only is either free or sold and so on.

If this equation is made operational by removing the function sign, it could take the form of;

$$
\mathrm{Vc}_{\mathrm{t}}=\beta_{\mathrm{o}}+\beta_{1} \mathrm{Sr}_{\mathrm{t}-\mathrm{n}}+\beta_{2} \mathrm{Ce}_{\mathrm{t}}+\varepsilon \text {-------------------co-creation}
$$

And

$$
\begin{array}{r}
\mathrm{Ce}_{\mathrm{t}}=\beta_{4}+\beta_{5} \mathrm{Sr}_{\mathrm{t}}+\beta_{6} \mathrm{Ci}_{\mathrm{t}}+\varepsilon \text {------interaction of firm and customer } \\
\mathrm{Sr}_{\mathrm{t}-\mathrm{n}}=\beta_{7}+\beta_{8} \operatorname{Pr}_{\mathrm{t}-\mathrm{n}}+\beta_{9} \mathrm{Pd}_{\mathrm{t}-\mathrm{n}}+\beta_{10} \mathrm{Pl}_{\mathrm{t}-\mathrm{n}}+\beta_{11} \mathrm{Pd}_{\mathrm{t}-\mathrm{n}}+\varepsilon \text {---- the firm's offer }
\end{array}
$$

Therefore logically the firm's efforts can assume several other simultaneous equations for $\operatorname{Pr}_{t-n}, P_{t_{-n}}, P_{t_{-n}}$ and $\mathrm{Pd}_{\mathrm{t}-\mathrm{n}}$

The goal of the firm in this situation would be to optimize

$$
\mathrm{Vc}_{\mathrm{t}}=\beta_{\mathrm{o}}+\beta_{1} \mathrm{Sr}_{\mathrm{t}-\mathrm{n}}+\beta_{2} \mathrm{Ce}_{\mathrm{t}}+\varepsilon \text {---------------------co-creation }
$$

Given

and

$$
\mathrm{Ce}_{\mathrm{t}}=\beta_{4}+\beta_{5} \mathrm{Sr}_{\mathrm{t}}+\beta_{6} \mathrm{Ci}_{\mathrm{t}}+\varepsilon \text {------------- interaction of firm and customer }
$$

$$
\mathrm{Sr}_{\mathrm{t}-\mathrm{n}}=\beta_{7}+\beta_{8} \mathrm{Pr}_{\mathrm{t}-\mathrm{n}}+\beta_{9} \mathrm{Pd}_{\mathrm{t}-\mathrm{n}}+\beta_{10} \mathrm{Pl}_{\mathrm{t}-\mathrm{n}}+\beta_{11} \mathrm{Pd}_{\mathrm{t}-\mathrm{n}}+\varepsilon----- \text { the firm's offer }
$$

\subsection{The firms' sales perspective and considerations}

The firm's sales would take the form: Sales is a function of marketing efforts before value creation $\mathrm{Me}_{\mathrm{t}-\mathrm{n}}$, marketing efforts during co-creation $\mathrm{Me}_{\mathrm{t}}$, marketing threats during co-creation $\mathrm{Mt}_{\mathrm{t}}$ and $\mathrm{Mo}_{\mathrm{t}}$ opportunities during co-creation. This can also be represented as

$$
\mathrm{S}_{\mathrm{t}}=f\left(\mathrm{Me}_{\mathrm{t}-\mathrm{n}}, \mathrm{Me}_{\mathrm{t}}, \mathrm{Mt}_{\mathrm{t}}, \mathrm{Mo}_{\mathrm{t}}\right)
$$

In all these equations time ' $t$ ', ' $t-n$ ' may or may not be equal; if ' $t-n$ ' is equal to ' $t$ ' then co-creation is possible, else $t$ is not equal to $t-n$ then marketing effort during value creation is necessary. Hence the emphasis on cocreation of value and need to synchronize the marketing organisation's efforts at consumption time with consumer's value creation as it goes on at time t-n. The firm's goal will be to optimize marketing efforts and would include, price, product, place and promotion as value vectors and they will be the same as the vectors in the equation for $\mathrm{Sr}_{\mathrm{t}-\mathrm{n}}$ and can be represented as follows

$$
\mathrm{Me}_{\mathrm{t}-\mathrm{n}}=\beta_{7}+\beta_{8} \mathrm{Pr}_{\mathrm{t}-\mathrm{n}}+\beta_{9} \mathrm{Pd}_{\mathrm{t}-\mathrm{n}}+\beta_{10} \mathrm{Pl}_{\mathrm{t}-\mathrm{n}}+\beta_{11} \mathrm{Pm}_{\mathrm{t}-\mathrm{n}}+\varepsilon
$$

Then if creation of value takes place as service delivery is provided then $\mathrm{n}=0$, and $\mathrm{t}=\mathrm{t}-\mathrm{n}$ then the sales equation would be

$$
\mathrm{S}_{\mathrm{t}}=f\left(\mathrm{Me}_{\mathrm{t}}, \mathrm{Mt}_{\mathrm{t}}, \mathrm{Mo}_{\mathrm{t}}\right)
$$

This is particularly important for those companies that deliver services as consumption takes place, the firm must, 
of necessity try to consciously insert itself (with permission) into the value creation process of the consumer. Therefore the firm is also to optimize

Given the constraining simultaneous equations for $\mathrm{Me}_{\mathrm{t}-\mathrm{n},}, \mathrm{Me}_{\mathrm{t}}, \mathrm{Mt}_{\mathrm{t}}$, and $\mathrm{Mo}_{\mathrm{t}}$

$$
\mathrm{S}_{\mathrm{t}}=f\left(\mathrm{Me}_{\mathrm{t}-\mathrm{n}}, \mathrm{Me}_{\mathrm{t}}, \mathrm{Mt}_{\mathrm{t}}, \mathrm{Mo}_{\mathrm{t}}\right)
$$

\subsection{Conclusion}

This paper set out to explore the new hotly debated SD Logic and has reviewed extant literature on service dominant logic' creation and co-creation of value arguments. It was found that enough theoretical bases for its application had been generated since Vargo and Lusch's (2004) publication of their article on SD logic. The foundational propositions have been critiqued, improved and till date, have been subjected to healthy and rigorous debates. Therefore, the foundations for making operational the service dominant logic in marketing had been laid. This study has tried to demonstrate that micro level models of different dimensions of the SD logic propositions can be developed. Though the model developed here have assumed linear relationships, it is conceptually feasible to construct non linear, relationships that can be empirically used for data of all type, that seek to validate differences, preferences, purchase decisions and so on. Though the macro analysis, that is, propositions to move from micro to macro levels of the marketing systems have not been discussed in this paper, they have been demonstrated by Layton (2011) as being feasible; a view also supported by Lamberti and Paladino (2013), Vargo and Lusch (2014) and Vargo and Lusch (2017) . Furthermore, Karpen et al (2012) have provided bases "to execute S-D logic in practice". Their article "devises an S-D orientation, specified as a portfolio of six strategic capabilities, namely individuated, relational, ethical, empowered, developmental, and concerted interaction capability. In combination, these six strategic capabilities constitute a co-creation capability." These are important because a consideration of the wider environments, relationship and resources would have been part of the firm's considerations prior to start of business.

Going forward, it would appear that the next step is to actually carry out empirical studies to validate or otherwise these propositioned models and raise new, more complex and encompassing conceptual frameworks, for say, branding decisions, in value creation situations, marketing mix decisions and so on. It is the belief of this paper that SD logic is a more involving logic that makes the firm to generate and maintain a dynamic and cyclical system of interaction, co-production of service offer and where co-creation of value can be optimized. This is in line with Vargo and Lusch (2017) observations that they can point to, the directions in which SD logic "seems to be headed: (1) toward a cohesive general theory (2) toward more specific, empirically testable and practically applicable, midrange theory and (3) toward expanded influence, both from and on, diverse disciplines and research streams, (e.g., institutional theory, practice theory, systems theory) and emerging micro level research initiatives (e.g., omni-channels, effectuation theory, reconfiguration theory)". We are in agreement with their insight so stated. Finally, the foregoing discussions notwithstanding, this paper does not claim to be exhaustive or definitive, but its usefulness lies in its demonstration that the time has come to start extensive research in this area and put this new dominant logic to scrutiny and academic and practical investigations.

Acknowledgement: The author wishes to thank Professor Vincent N. Ezeabasili, Department of Banking and Finance and Director, Centre for Entrepreneurial Studies, Chukwuemeka Odumegwu Ojukwu University Anambra State, Nigeria, for his immense contributions to improving the quality of drafts of this article. We wish to express our profound gratitude for the guidance and encouragement to publish given by Professor Anayo Nkamnebe and Professor I. C. Nwaizugbo, both of the Department of Marketing, Faculty of Management Sciences, and both supervisors in my current doctoral degree research programme.

\section{References}

Abela, A. V. and. Murphy, P. E (2008). Marketing with integrity: ethics and the service-dominant logic for marketing. Marketing Theory, 36, 39-53.

Arnould, E. J. (2006). Service-dominant logic and consumer culture theory: Natural allies in an emerging paradigm. Marketing Theory 6(3): 293-298.

Ballantyne, D., Williams, J. and Aitken, R. (2011). Introduction to service-dominant logic: from propositions to practice. Industrial Marketing Management. 40: 279-280.

Brodie , R. J., Glynn, M. S. and Little, V. (2006). The service brand and the service-dominant logic: missing fundamental premise or the need for stronger theory? Marketing Theory, 6(3): 363-379, [Online] Available http://mtq.sagepub.com/cgi/content/refs/6/3/363 [ September 8th 2017].

Fuentes, M. and Smyth, H. (2016). Value Co-Creation in a Project Setting: A Service-Dominant Logic Perspective. In: P W Chan and Neilson, C J (Eds.) Proceedings of the $32^{\text {nd }}$ Annual ARCOM Conference, 57 September 2016, Manchester, UK, Association of Researchers in Construction Management, 2: 10591068.

Grönroos, C. (2006) Adopting a service logic for marketing. Marketing Theory, 6(3): 317-333.

Gronroos, C. (2011). Value co-creation in service logic: A critical analysis. Marketing Theory 11(3): $279-301$. 
Kanagal, N. B. (2014). Conceptualizing objective setting and metrics in marketing strategy. Journal of Management and Marketing Research, 16: 1-26.

Karpen, I. O., Bove, L. L. and Lukas, B. A. (2012). Linking service-dominant logic and strategic business practice: a conceptual model of a service-dominant orientation. Journal of Service Research 15(1): 21-38

Lamberti, L. and Paladino, A. (2013). Moving forward with service dominant logic: exploring the strategic orientations of a service-centred view of the firm. Int. Journal of Business Science and Applied Management 8(1): 1-15.

Layton, R. A. (2008). The search for a dominant logic: a macromarketing perspective. Journal of Macromarketing 28(3): 215-226.

Londhe, B. R. (2014). Marketing mix for next generation marketing. Procedia Economics and Finance 11: $335-$ 340.

Lusch, R. F. and S. L. Vargo (2006). The Service-Dominant Logic of Marketing: Dialog, Debate, And Directions. Ed. New York, M.E. Sharpe.

Lusch, R. F. and S. L. Vargo, (2006a). The service-dominant logic of marketing: Reactions, reflections, and refinements. Marketing Theory, 6(3), 281-288.

Lusch, R. F., Vargo, S. L., and O’Brien, M. (2007). Competing through service: insights from service-dominant logic. Journal of Retailing, 83(1), 5-18.

Lusch, R.F., Vargo, S. L., and Tanniru, M. (2010). Service, value networks and learning. Journal of the Academy of Marketing Science. 38(1): 19-31.

Michel, S., Stephen, W., and Gallen, A. S. (2008). Exploring and categorizing discontinuous innovations: A service-dominant logic perspective. Journal of the Academy of Marketing Science, 36: 54-66.

Shaw, E. H and Jones, D. G. B. (2005). A history of schools of marketing thought. Marketing Theory 5(3): 239281

Vargo, S. L. and Akaka, M. A. (2009). Service-dominant logic as a foundation for service science: clarifications. Service Science 1(1):32-41. https://doi.org/10.1287/serv.1.1.32

Vargo, S. L. and Lusch, R. F. (2004). Evolving to a new dominant logic for marketing. Journal of Marketing. 68: $1-17$.

Vargo S. L. and Lusch, R. F. (2008). Service-dominant logic: continuing the evolution. Journal of the Academy of Marketing Science, 36:1-10.

Vargo, S. L. and Lusch, R. F. (2014). Inversions of service-dominant logic. Marketing Theory 14(3): 239-248.

Vargo, S. L. and Lusch, R. F. '(2017) Service-dominant logic 2025. International Journal of Research in Marketing 34, 46-67. 